\title{
Adult Hemangioma of The Larynx in A Developing Community
}

\author{
Wilson I B Onuigbo ${ }^{1 *}$ and Benson C Okafor ${ }^{2}$ \\ Departments of Pathology and Otolaryngology, The University of Nigeria Teaching Hospital, Enugu 400001, Nigeria
}

Submission: July 16, 2018; Published: July 27, 2018

*Corresponding author: Wilson Onuigbo, Departments of Pathology and Otolaryngology, The University of Nigeria Teaching Hospital, Nigeria, Email: wilson.onuigbo@gmail.com

\section{Abstract}

Few adult hemangiomas of the larynx have been reported. There are a few cases published from India, Pakistan, Turkey, and Taiwan. Therefore, a Nigerian case is presented here from the Igbo Ethnic Group domiciled in South Eastern Nigeria.

Keywords: Adulthood Hemangioma; Larynx; Igbo; Nigeria

\section{Introduction}

There are a few reported individual cases of adult hemangiomas of the larynx published from India [1,2], Pakistan [3], Turkey [4,5], Taiwan [6] and China [7]. Therefore, we present such a case seen among the Igbo ethnic group [8], which is domiciled in the South Eastern Region of Nigeria.

\section{Case Report}

$\mathrm{AI}$, a 50-year-old male of the Igbo ethnic group, consulted one of us (BCO) on account of hoarseness of 5 years duration. Direct laryngoscopy revealed a fleshy, red polyp in the right vocal cord. This was biopsied and submitted to the co-author (WIBO). It was a tiny reddish piece. On microscopy, the appearance was classically that of cavernous hemangioma. It was complicated by partial thrombosis. Postoperatively, the patient's voice was improved, and the stridor was relieved. Altogether, his recovery was uneventful.

\section{Discussion}

Of the above intercontinental cases, all were single except the two from a Turkish center [5]. Their ages ranged from 22 years to 61 years (means 41 years). This is not as old as the local case. As in our case, the reported examples did well after aseptic surgical excision. Postoperatively, there was voice improvement. In sum, uneventful recovery occurred.Incidentally, the first re ported case was in 1871 while the etiologic factors have been thought to be vocal abuse and cigarette smoking [4]. Curiously, the sex factor seems not to have been considered. However, only 2 females appeared as against seven males in the present cohort.

\section{References}

1. Deenadayal DS, Kumar BN, Vidyasagar D, Praveen T (2017) A new modality of treatment for adult laryngeal haemangioma by coblation: A case report. Intl J Otolaryngol Head Neck Surg 6(3): 23-27.

2. Lodha J, Sharma A, Dabholkar J, Virmani N (2015) Unusual presentation of laryngeal cavernous hemangioma. Intl J Phonosurg Laryngol 5(2): 67-69.

3. Akhtar S, Shamim AA, Ghaffar S, Sheryar M (2012) Adult laryngeal haemangioma: A rare entity. J Pakins Med Assoc 62(2): 173-174.

4. Karatayli-Ozqursoy S, Basaran M, Umudum H, Akmansu SH (2015) Adult laryngeal hemangioma: A rare case report. Otolaryngology 5(4): 201.

5. Dogan M, Ozgursoy OB, Muz SE (2010) Management of laryngeal hemangioma in adults: A care report. Kulak Burun Bogaz Ihtis 20(6): 314-317.

6. Yu-HsingLin, Hsu-CheuhHo (2010) Adult laryngeal hemangioma. Tzu Chi Med J 22(4): 237-240.

7. Wang X, Zhao X, Zhu W (2015) Resection of a laryngeal hemangioma in an adult using an ultrasonic scalpel: A case report. Oncology Letters 9(6): 2477-2480.

8. Basden, GeorgeThomas (1966) Niger Ibos. Lond. 
CC (1) This work is licensed under Creative BY DOI: 10.19080/GJO.2018.16.555949
Your next submission with Juniper Publishers will reach you the below assets

- Quality Editorial service

- Swift Peer Review

- Reprints availability

- E-prints Service

- Manuscript Podcast for convenient understanding

- Global attainment for your research

- Manuscript accessibility in different formats

( Pdf, E-pub, Full Text, Audio)

- Unceasing customer service

Track the below URL for one-step submission https://juniperpublishers.com/online-submission.php 